\title{
Immune Response Regulation by Antigen Receptors' Clone-Specific Nonself Parts
}

\author{
Hilmar Lemke* \\ Biochemical Institute of the Medical Faculty, Christian-Albrechts-University at Kiel, Kiel, Germany
}

Antigen determinants (epitopes) are recognized by the combining sites (paratopes) of $B$ and $T$ cell antigen receptors (BCR/TCR), which again express clone-specific epitopes (idiotopes) that can be recognized by BCR/TCR not only of genetically different donors but also within the autologous immune system. While xenogeneic and allogeneic anti-idiotypic BCR/TCR are broadly cross-reactive, only autologous anti-idiotypes are truly specific and of functional regulatory relevance within a particular immune system. Autologous BCR/TCR idiotopes are (a) somatically created at the third complementarity-determining regions, (b) through mutations introduced into BCRs during adaptive immune responses, and (c) through the conformational impact of both. As these idiotypic characters have no genomic counterparts they have to be regarded as antigen receptor-intrinsic nonself-portions. Although foreign, however, they are per se non-immunogenic, but in conjunction with immunogenicity- and adjuvanticity-providing antigen-induced immune responses, they induce abating regulatory idiotypic chain reactions. The dualistic nature of antigen receptors of seeing antigens (self and nonself alike) and being nonself at the same time has far reaching consequences for an understanding of the regulation of adaptive immune responses.

Keywords: B cell antigen receptor (BCR), T cell antigen receptor (TCR), adaptive immune response, regulation, idiotype, self-nonself, immunogenicity, transgenerational imprinting

\section{THE CLONAL SELECTION THEORY - KEYSTONE OF IMMUNOLOGY}

The clonal selection theory put forward almost 60 years ago (1) has developed into the clonal selection law (CSL) (2) that is widely accepted as keystone and current paradigm of adaptive immunity and immunological thinking in general (3-5). The core features of CSL comprise that (i) membranebound antigen receptors of $\mathrm{B}$ cells (BCR) and T cells (TCR) are generated in an antigen-independent genetic process, (ii) these preformed receptors are specific for particular antigens and thus mediate the specific clonal selection of the relevant cells encountering the corresponding antigen during microbial infections or experimental immunizations, and (iii) depending on antigen parameters like quantity, quality [various parameters determining its immunogenicity including size, structure, ability to induce cytokine responses after binding to non-clonal receptors on antigen-presenting cells, presentability of antigen fragments via major histocompatibility complex (MHC) molecules, etc.], route of entry, place of action in tissues, presence of natural microbial or admixed adjuvants, and the genetic constitution of the host $(2,6)$ such interactions may either lead to activation and proliferation of the respective $\mathrm{B}$ and $\mathrm{T}$ cells that execute the ensuing immune response (leading to 
differentiation into end stage effector and memory cells) or to the induction of tolerance by a variety of mechanisms. It is of historic interest that in 1955 , Jerne $(7,8)$ proposed that natural antibodies (nAbs) make the first encounter with antigen and thus support a theory of antibody-selection driven adaptive immune response (9).

\section{ANTIGEN-SPECIFIC INITIATION AND NON-SPECIFIC PROGRESSION OF ADAPTIVE IMMUNE RESPONSES?}

Thus, BCR and TCR mediate the initiation of adaptive immune responses. While cell-bound BCR directly react with native antigens, the diverse subpopulations of naïve T cells like $\mathrm{CD}^{+}$cytotoxic cells and a multitude of helper and suppressor $\mathrm{CD}^{+} \mathrm{T}$ cells $\left[\mathrm{T}_{\mathrm{H}} 1, \mathrm{~T}_{\mathrm{H}} 2, \mathrm{~T}_{\mathrm{H}} 17\right.$, follicular helper $\mathrm{T}$ cells $\left(\mathrm{T}_{\mathrm{FH}}\right)$, and regulatory T cells (Tregs)] (10) can only participate in adaptive responses after antigen has been taken up and degraded by various antigenprocessing cells which then present antigen fragments on MHC molecules on the cell surface. Depending on the nature of the antigen, immune responses develop along different pathways. The initial encounter of BCR/TCR with thymus-dependent (TD) antigens, in particular hapten-coupled proteins as model antigens, induce partial activation, proliferation, differentiation, and migration through secondary lymphoid organs and cellular interactions beginning at extrafollicular sites and continuing in B cell follicles with the establishment of germinal centers (GCs) [reviewed in Ref. (11-15)]. In the GCs, B cells undergo extensive $\mathrm{T}_{\mathrm{FH}}$-dependent proliferation and somatic hypermutations (SHM) that are accompanied by class-switch recombination (CSR) and immune maturation through selection of higher affinity clones. The GC responses not only lead to differentiation of class-switched memory B cells that participate in secondary responses since they can be activated in the presence of humoral antibody (16) but also to long-lived plasma cells that secrete high amounts of antibody independently of antigen and to memory B cells (17). By contrast, immune responses to complex antigens like Salmonella typhimurium can also develop independently of GC formation in follicles and extrafollicular sites and this response is also accompanied by CSR and SHM-mediated immune maturation (18). Even the heterogeneous populations of memory B cells may be generated in as well as outside GCs (19) and may retain IgM BCR on their cell surface (20). In addition, a special B cell memory can also be induced by thymus-independent type I (TI-1-mitogenic) and type II (TI-2-polymeric) antigens (21) and this type of memory is related to antigen-specific IgG antibodies $(22,23)$.

The complex events of cellular interactions, proliferation, differentiation, and migration during progression of adaptive immune responses through the different specialized microenvironments of secondary lymphoid organs are studied by associating the involved cell lineages with the expression of transcription factors, activation and differentiation markers, cytokine and chemokine secretion, and expression of the respective membrane receptors [reviewed in Ref. $(11-13,19,24)]$. The main driving force during GC differentiation is supposed to depend on the selection of higher affinity clones that are generated by SHM (25). However, in response to two complex antigens (Bacillus anthracis protective antigen and influenza hemagglutinin) half of the GC B-cells did not bind the antigen used for immunization despite showing signs of activation, namely biased usage of $\mathrm{VH}$ genes, exhibition of mutations, and clonal proliferation similar to antigen-binding B cells (26). Also in the initial extrafollicular response to the complex antigen S. typhimurium, only a small fraction of B-cells showed specific binding to the antigen and underwent SHMdriven immune maturation while the majority of cells did not bind antigen (18). Although these antigen non-specific responses are not understood, it currently appears to be generally accepted that, after antigen-dependent BCR/TCR-specific initiation of adaptive immune responses, all further steps of $\mathrm{B}$ and $\mathrm{T}$ cell differentiation that depend on the initial clonal selection are associated with and can be described by the expression of non-clonal and antigennon-specific factors as mentioned above.

However, this view completely ignores investigations made some decades ago, which proclaimed that the antigen-specific initiation of the response is followed by a cascade-like chain reaction directed at clonotypic/idiotypic determinants in the variable regions of BCR and TCR. These investigations had led to the hypothesis of an idiotypic network that is functionally active before any encounter of environmental antigens and involved in regulation of immune responses as well (27). Publication rates for the term "idiotype" reveal this temporary interest that increased 1978-1988 and decreased to a low level during the next decade while related keywords, as for instance, "B cell antigen receptor" and " $T$ cell antigen receptor" document a prolonged and more constant interest; however, for "regulatory T cell" a rather dramatic change in interest is visible (Figure 1). Investigations on idiotypic regulation have been viewed as "tidal wave" that "has receded leaving behind an empty beach" (28). Accordingly, idiotypic research once regarded as the cutting edge of immunology is nowadays even eliminated from most textbooks that only denote the term "idiotype" without ascription of any functional relevance $(4,5)$. A detailed description of this "Rise and Fall of a Scientific Paradigm" has been composed by Eichmann (29) in which he wondered (p. 3): "How can such a thing happen? How is it possible that hundreds of scientists engage in work, over periods of more than a decade, that thereafter gets disposed as meaningless?" Ironically enough, despite this condemnation his work also contains statements from 11 well-known former idiotype-researchers as key-witnesses of this time that "an immune network exists" (p. 157) and "idiotype-based regulations exists" (p. 161) and that it "was all solid work" (p. 166). This is an extremely disappointing situation calling for a solution; it certainly does not allow idiotypic research on regulation to be simply filed away as if it had never happened. A recent review of the current understanding of idiotypic research summarizes the expectation and return of studies on the idiotypic network (30).

\section{PRINCIPLE REACTIONS IN IDIOTYPIC REGULATIONS}

In 1963, antigen-induced antibodies themselves were found to be immunogenic and can induce anti-antibodies $(31,32)$ that reacted with specific determinants of the inducing antibodies (idiotypes or 


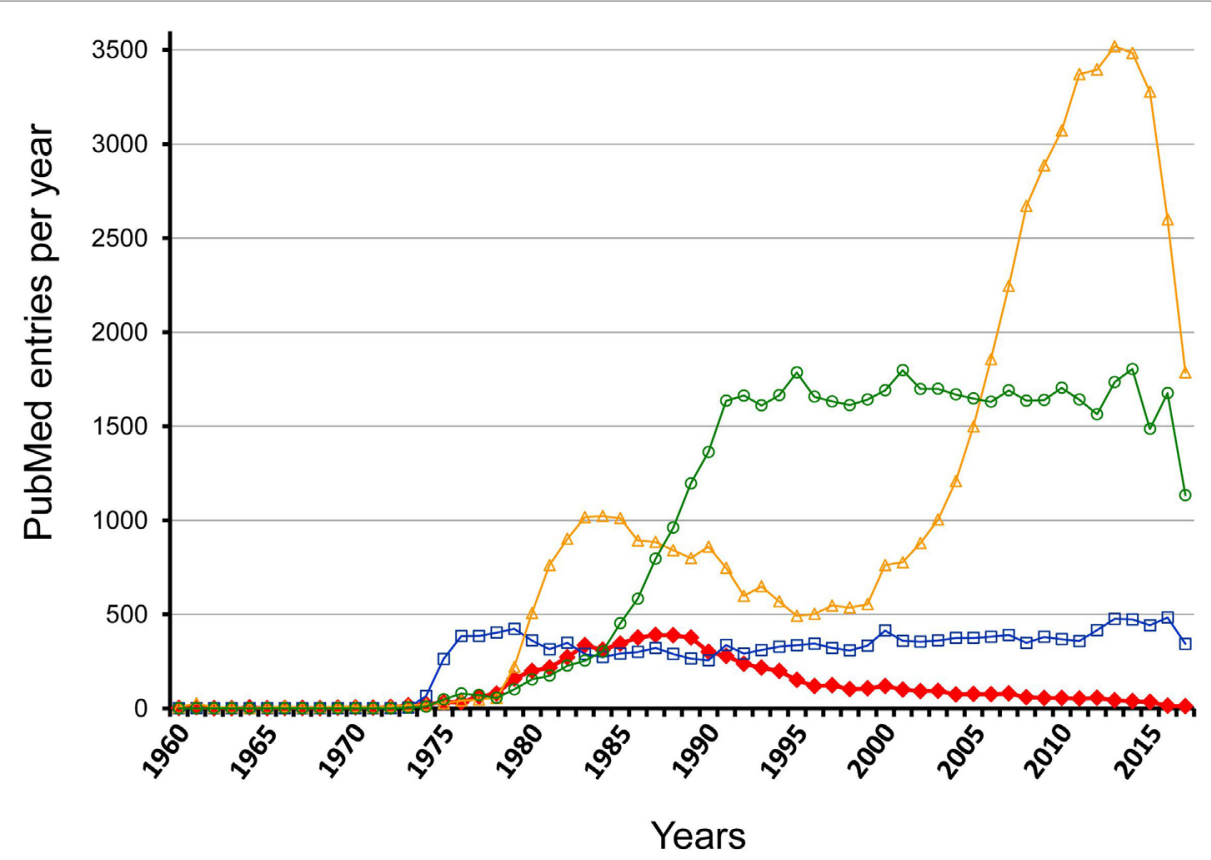

FIGURE 1 | Comparison of PubMed entry "idiotype" with related marks per year between 1960 and 2017. The figure shows the results of a PubMed search for the following keywords: idiotype-red filled rhombus; regulatory T cell-yellow open triangles; B cell antigen receptor-blue open squares; T cell antigen receptor-light green open circles.

$\mathrm{Ab} 1)$ and so were designated anti-idiotypes (Greek $1 \delta 10 \sigma$, unique). Anti-idiotypic (Ab2) antibodies represent a heterogeneous group recognizing different types of idiotypic determinants (idiotopes) and are classified on the basis of their reactivity with Ab1 idiotopes in variable distances from the antigen combining site (paratope) [reviewed in Ref. (33)]. (a) Ab2 $\alpha$ react with idiotopes located outside the paratope in vicinity to and in framework regions and their binding to Ab1 cannot be inhibited by antigen. (b) Although another set of $\mathrm{Ab} 2(\mathrm{Ab} 2 \gamma)$ recognize paratope-associated idiotopes, their binding to $\mathrm{Ab} 1$ can also not be inhibited by antigen. (c) Anti-idiotypic antibodies of the Ab2 $\beta$ type react with idiotopes that overlap or even may supposedly coincide with the Ab1 paratope. The antigen-inhibitable reactivity of these $A b 2 \beta$ has been taken as indication that the paratopes of particular $\mathrm{Ab} 2 \beta$ resemble the antigenic epitope and thus may carry an internal images of it (34). Hence, this type of $\mathrm{Ab} 2$ can be employed as surrogate antigen $(35,36)$. However, structural analyses have shown that the mimicking of antigenic epitopes is functional and mediated by similar binding interactions, but does not depend on identical 3D structures (37). This nonstructural but functional mimicry can even be observed with anti-idiotypic antibodies reacting with $\mathrm{Ab} 1$ to nonprotein antigens. For instance, although $\mathrm{Ab} 2$ are certainly not able to mimic a polysaccharide structure they may induce a polysaccharide-specific response to the related antigen $(38,39)$. Hence, since true internal images of external epitopes seemingly do not exist, it has been proposed to replace the "internal image" concept as well as the designations for the different $\mathrm{Ab} 2$ subtypes by be term "network antigens" (40). (d) A fourth type of anti-idiotypes are $A b 2 \varepsilon$ antibodies or epibodies which not only display an Ab1-directed anti-idiotypic reactivity but also react with an epitope of the related antigen (41). Interestingly, Ab2 antibodies that are similar to but distinct from $\mathrm{Ab} 2 \varepsilon$ have been described, which not only exhibit Ab1-binding anti-idiotypic but also antigen-binding as well as self-binding activities $(42,43)$.

Contrary to their nomination, idiotypes not only carry clone/ individually specific (IdI) but also cross-reactive idiotopes. On the one hand, such cross-reactive idiotopes (IdX or CRI) have been observed on antibodies exhibiting a particular antigen-specificity as shown in the antibody response of $\mathrm{BALB} / \mathrm{c}$ mice to the random synthetic terpolymer of $\left(\mathrm{Glu}^{60} \mathrm{Ala}^{30} \mathrm{Tyr}^{10}\right) \mathrm{n}(\mathrm{GAT})$ that are characterized by the cross-reactive or public idiotype pGAT, which is detected with a xenogeneic rabbit antiserum (44). Likewise, antibodies reacting with the hapten p-azobenzenearsonate (ABA) can exhibit different families of CRIs (45). On the other hand, idiotypic cross-reactivity is even exhibited by antibodies that are stimulated by different external antigens. Already in 1971 it was observed that idiotypic specificities could be expressed by immunoglobulins with different binding specificities (46). For instance, murine 2,4-dinitrophenyl (DNP) antibodies carry the Id460-idiotype which is also expressed on antibodies reacting with the mouse pathogen Pasteurella pneumotropica (47). A particular idiotope $\left(\mathrm{B}^{+}\right)$of anti-dextran antibodies in $\mathrm{BALB} / \mathrm{c}$ mice is expressed on a subset of antibodies from $\mathrm{A} / \mathrm{J}$ mice that react with the hapten NIP (48). An idiotope of a BALB/c levan-specific myeloma protein that is defined by a syngeneic monoclonal $\mathrm{Ab} 2$ is expressed on monoclonal antibodies of different mouse strains that are encoded by $\mathrm{V}$ region genes other than the corresponding myeloma and react with different nonself- and self-antigens (49). Moreover, common idiotopes have also been detected on anti-DNA auto-antibodies binding to different autoantigens (50). 
Anti-idiotypic responses can not only be induced to antigenreactive $\mathrm{Ab} 1$ but also to anti-idiotypic Ab2 antibodies. For instance, such anti-anti-idiotypic antibodies (Ab3) have been induced in rabbits that have been immunized with a polyclonal preparation of $\mathrm{Ab} 2$ which were induced with purified hyperimmune Ab1 reacting with the carbohydrate of Micrococcus lysodeikticus bacteria (51). Although these Ab3 shared idiotypic specificities with the corresponding Ab1, they did not react with the antigen. However, when these Ab2-immunized Ab3producing rabbits were immunized with $M$. lysodeikticus, they produced anti-carbohydrate antibodies $\left(\mathrm{Ab}^{\prime}\right)$ that idiotypically resembled Ab1. Hence, the composition of the antigen-activated repertoire depends on the idiotypic history of an individual. This conclusion has been corroborated, among others, in a syngeneic experimental system in $\mathrm{BALB} / \mathrm{c}$ mice, which were immunized with a levan-binding myeloma protein. These mice not only produced Ab2 but also Ab3 antibodies which could further be applied to induce anti-anti-anti-idiotypes (Ab4) (52). The members of this idiotypic cascade are idiotypically connected in that $\mathrm{Ab} 3$ and $\mathrm{Ab}^{\prime}$ share a cross-reactive regulatory idiotope that reacts with both $\mathrm{Ab} 2$ and $\mathrm{Ab} 4$. In addition, the immune response to the related antigen levan could be variably influenced by the state of activation of $\mathrm{Ab} 2, \mathrm{Ab} 3$, and $\mathrm{Ab} 4$ of this idiotypic cascade (52). Such Ab2-reactive regulatory idiotopes on nonprotein antigens have also been observed in responses to steroid hormones, ligands, or drugs and glycolipids [reviewed in Ref. (33)]. Regulatory idiotopes were supposed to allow a communication between immune responses to different antigens and thus are fundamental for functioning of the idiotypic network (27). Needless to say, the sequential steps of the idiotypic cascade have also been detected in humans, e.g., during treatment of cancer patients with therapeutic antibody (53).

The reactivities in the idiotypic cascade allow two important conclusions to be drawn. First, although antigen-induced Ab1 can give rise to an anti-idiotypic response (Ab2) an immunization with $\mathrm{Ab} 2$ never induces the set of Ab1. This rule also applies for the next steps in the cascade. Hence, the idiotypic cascade only proceeds in a forward direction and not backwards. This is important since it has been concluded by Jerne (7) and others that "recognizing" and "being recognized" cannot be distinguished and that it is, therefore, meaningless to distinguish between idiotopes and combining sites. If this were the case, it could be argued that immunization with Ab2 should activate the whole set of antigen-induced Ab1. This, however, is not the case. Instead, Ab2 induces Ab3 that only in rare cases may contain antigen-binding $\mathrm{Abl}^{\prime}$, which in addition are genetically different from Ab1. Second, immune responses to antibodies (Ab1, Ab2, and further) can only be induced after coupling to a carrier as, for instance, keyhole limpet hemocyanin that provides sufficient immunogenicity and with strong adjuvants and/or the help by different other means (54). Such efforts are absolutely inevitable for idiotypic/anti-idiotypic vaccinations of patients suffering from tumors or microbial infections $(55,56)$.

The extensive work on idiotypic regulation of adaptive immune responses allowed the statement "that the immune system of a single animal after producing specific antibodies to an antigen, continues to produce antibodies to the idiotopes of the antibodies that it has itself made" (7). This conclusion is based on the following principle idiotypic specificities and cellular interactions within a particular immune system [reviewed in Ref. $(7,57,58)$ ].

- The immune system contains anti-idiotypic B and T cell specificities for all antigen-specific BCR and TCR that have been investigated in this respect $(29,59)$.

- Idiotypic recognition occurs among B cells/antibodies $(7,27)$.

- TCR can be recognized by anti-idiotypic BCR/antibodies in an MHC-non-restricted fashion (60-63).

- BCR are recognized by anti-idiotypic TCR in an MHCrestricted way (64-69).

- MHC-restricted idiotypic recognition occurs among $\mathrm{T}$ cells $(70,71)$.

Despite these admittedly undeniable experimental evidences $(72,73)$ that were compiled in multiple experimental systems it was possible to state that "it is safe to say that we never learned anything from it" and that "the idiotype network theory of regulation lacked logic and rationale" (28) or to conclude that "everything you can imagine to happen in the idiotypic network, you can make happen; but the physiological impact of these reactions remained elusive" [K. Rajewsky in (29), p. 165]. Thus, a plethora of experimental results did not lead to a conceptual explanation as to why these interactions are induced. Were decisive experiments still missing? A solution to this key problem would have needed a clear comprehension about the principle nature of idiotopes as antigenic determinants that specifically characterize a particular idiotype.

\section{CHARACTERIZATION OF IDIOTOPES}

A particular BCR/TCR idiotype is composed of a collection of different idiotopes. Initially, idiotypes were characterized with absorbed xenogeneic and then allogeneic antisera before it became possible to properly identify individual idiotopes with monoclonal anti-idiotypic antibodies. However, anti-idiotypes of xenogeneic and allogeneic origin are generally broadly cross-reactive and thus are actually not idiotype-specific (74). Since a hypothetical physiological idiotypic network is exclusively functioning within a particular immune system (and at best between mother and fetus), autologous anti-idiotypes are actually mandatory for its investigation. Autologous anti-idiotypes have the highest discriminatory power and are truly specific for a given idiotope and therefore for the whole idiotype. For practical reasons syngeneic anti-idiotypes represent a reasonable compromise [reviewed in Ref. (74)]. During the entire research on idiotypic regulation, it could not be clarified whether idiotopes are non-inheritable individually specific characters or whether they are useful genetic markers. Thus, a generally applicable view of the nature of idiotopes in the BCR/ TCR variable regions has not been presented. This is remarkable since the assembly of $\mathrm{B}$ and $\mathrm{T}$ cell antigen receptors from a set of gene segments in the primary lymphoid organs is well known. For a clear characterization of idiotopes, it seems advisable to briefly repeat the construction of BCR and TCR.

In contrast to the limited number of receptors and corresponding ligands, which, after clonally selected initiation of the response, mediate the further clonal development (activation markers, cytokines, interleukins, etc.) BCR/TCR are destined for and indeed able to recognize a seemingly unlimited number 
not only of environmental and autologous antigens but also of synthetic non-natural antigens. It is obvious that this task cannot be performed with a limited set of genomically encoded receptors. Thus, how can the immune system cope with this challenge? The generally accepted explanation is seen in the recombination of gene segments that together code for the variable domains of antigen receptors of BCR as well as both types of TCR exhibiting $\mathrm{TCR}_{\alpha \beta}$ or $\mathrm{TCR}_{\gamma \delta}$ receptors. All three are assembled from multiple $\mathrm{V}$ gene segments, diversity enhancing $\mathrm{D}$ gene segments, and J gene segments that join the variable portion with constant gene segments $(75,76)$. While variable regions of antibody light chains $\left(\mathrm{V}_{\mathrm{L}}\right), \mathrm{TCR}_{\alpha}$, and $\mathrm{TCG}_{\gamma}$ chains are assembled from $\mathrm{V}$ and $\mathrm{J}$ gene segments, those of antibody heavy chains $\left(\mathrm{V}_{\mathrm{H}}\right), \mathrm{TCR}_{\beta}$, and $\mathrm{TCR}_{\delta}$ chains are composed of $\mathrm{V}, \mathrm{D}$, and $J$ gene segments. This $\mathrm{V}(\mathrm{D}) \mathrm{J}$ recombination allows already for huge hypothetical combinatorial BCR and TCR repertoires both of which, in addition, are greatly enhanced by inaccuracies that are introduced during the recombination process. However, a functional regulatory relevance (see below) has not been ascribed to these imprecisions which are somatically generated in three different ways.

(1) During V(D)J recombination, DNA hairpins are generated which may be opened asymmetrically. Thereby, a few nucleotides of one strand plus their complementary nucleotides from the reverse strand form a single-stranded tail. Filling-in of the second strand generates a palindromic sequence. In this way, a few nucleotides ( $\mathrm{P}$ nucleotides) of the reverse strand are transferred to the coding sequence where they alter the information of the respective segment $(75,77-80)$.

(2) A quantitatively much more important modification at both recombination sites (V-D and D-J) of the BCR heavy chain (but only insignificantly at the light chain) as well as all four polypeptide chains of both types of TCR is created by the enzyme terminal deoxynucleotidyl transferase (TdT) that inserts non-templated nucleotides ( $\mathrm{N}$-nucleotides) at variable ratios $(75,81,82)$. It has been estimated that $\mathrm{TdT}$ function is, for instance, at least responsible for $90 \%$ of the $\mathrm{TCR}_{\alpha \beta}$ repertoire (83). In contrast to the $\mathrm{BCR} \mathrm{V}_{\mathrm{L}}$ region, $\mathrm{V}$-Jencoded $\mathrm{TCR}_{\alpha}$ and $\mathrm{TCR}_{\gamma}$ chains also contain high numbers of $\mathrm{N}$-nucleotides (76).

(3) Another equally important modification during BCR/TCR $\mathrm{V}(\mathrm{D}) \mathrm{J}$ recombination is introduced by exonuclease-mediated deletion of nucleotides from the $3^{\prime}$-end of $\mathrm{V}$ gene segments, both ends of the $\mathrm{D}$ gene segments and the $5^{\prime}$-end of the J gene segments $(75,76,83)$.

Hence, while the first two complementarity-determining regions (CDR1 and CDR2) of all BCR and TCR chains are fully encoded in the genome, the coding sequences of all CDR3s are somatically created. This is exemplarily outlined in Figure $\mathbf{2}$ for the VDJ recombination coding for the $\mathrm{V}_{\mathrm{H}}$ domain of immunoglobulins. The genomic gene segments are modified by nucleotide deletions and additions of $\mathrm{P}$ and $\mathrm{N}$-nucleotides to such an extent that the final products of CDR-H3 are specifically created for each B cell clone. Accordingly, CDR-H3 sequences are generally used as specific marker for the identification of particular B cell clones

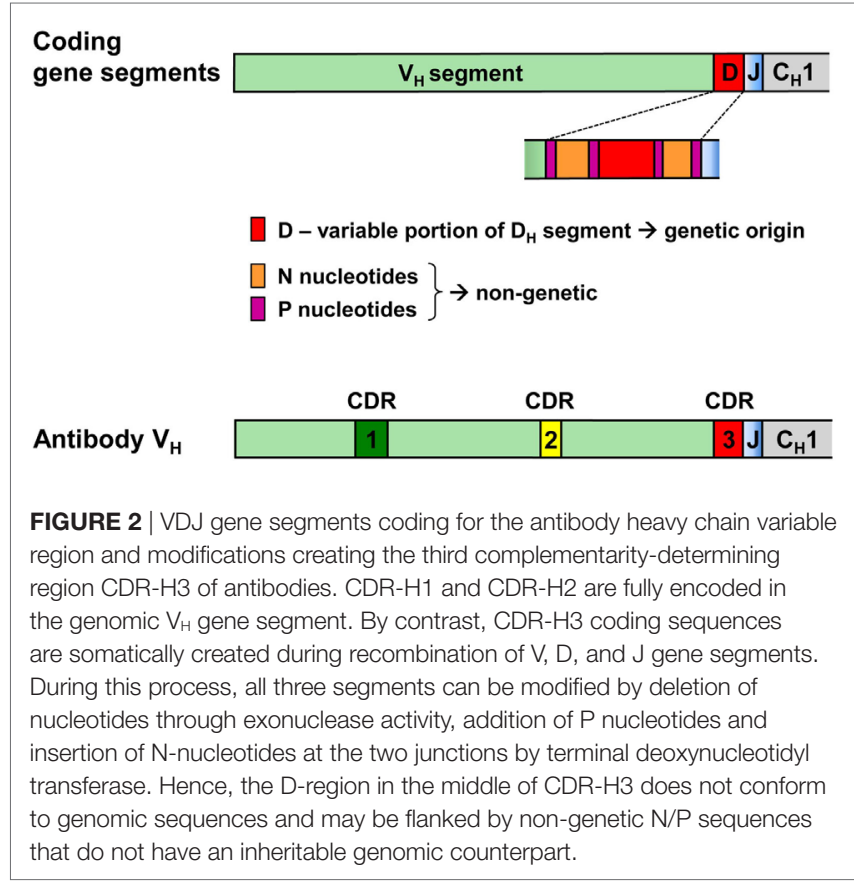

(26) and TCR CDR3 for T cell clones (84). Remarkably, the specificity of T cells is basically determined by TCR CDR3 with their almost unlimited variability (85). A quantitative impression of antibody CDR-H3 imprecisions is depicted in Figure 3 showing nucleotide deletions and additions of monoclonal antibodies that were obtained from $\mathrm{BALB} / \mathrm{c}$ mutant mice containing a single altered $\mathrm{D}$ gene segment after immunization with chicken serum albumin coupled with the hapten 2-phenyl-oxazolone (phOx), one of the "classical" model immune responses (86) [data taken from Ref. (87)]. Although a certain proportion of these monoclonal antibodies exhibited neither deletions nor additions of nucleotides at both recombination sites $\mathrm{V}_{\mathrm{H}}-\mathrm{D}$ and $\mathrm{D}-\mathrm{J}_{\mathrm{H}}$, none of the antibodies used a full genomic combination of VDJ gene segments. At both sides of the D segment up to 16 of 26 nucleotides could be deleted (Figures 3C,D) and 15 nucleotides at $5^{\prime}$-end of $\mathrm{J}_{\mathrm{H}}$ (Figure 3F). What is even more remarkable, in $23 \mathrm{mAb}(28 \%)$ the $\mathrm{D}_{\mathrm{H}}$ sequence was truncated to such an extent that it could not be detected (data not shown). Similar results were obtained in another D-altered mouse strain (87). As we also did not find fully genomically encoded antibodies in a large group of phOx-specific antibodies from immunized as well as non-immunized BALB/c wild-type mice $(23,88)$, does this imply that there is no genomic VDJ combination with specificity for the hapten phOx?

In addition, it has to be asked as to whether antibodies exist at all, which are encoded by complete genomic V, D, and J gene segments without recombination-introduced inaccuracies as the assumption of a combinatorial repertoire suggests? Antibodies as products of antigen-stimulated adaptive immune responses are produced by "conventional" or so-called B-2 cells (89). To the best of my knowledge, in repertoire analyses of B-2 cell antibodies of adult mice full genomic sequences have not been found as exemplarily shown in Ref. (90-92) as well as in a large collection of sequences of anti-phOx antibodies $(23,87,88,93)$. In contrast 


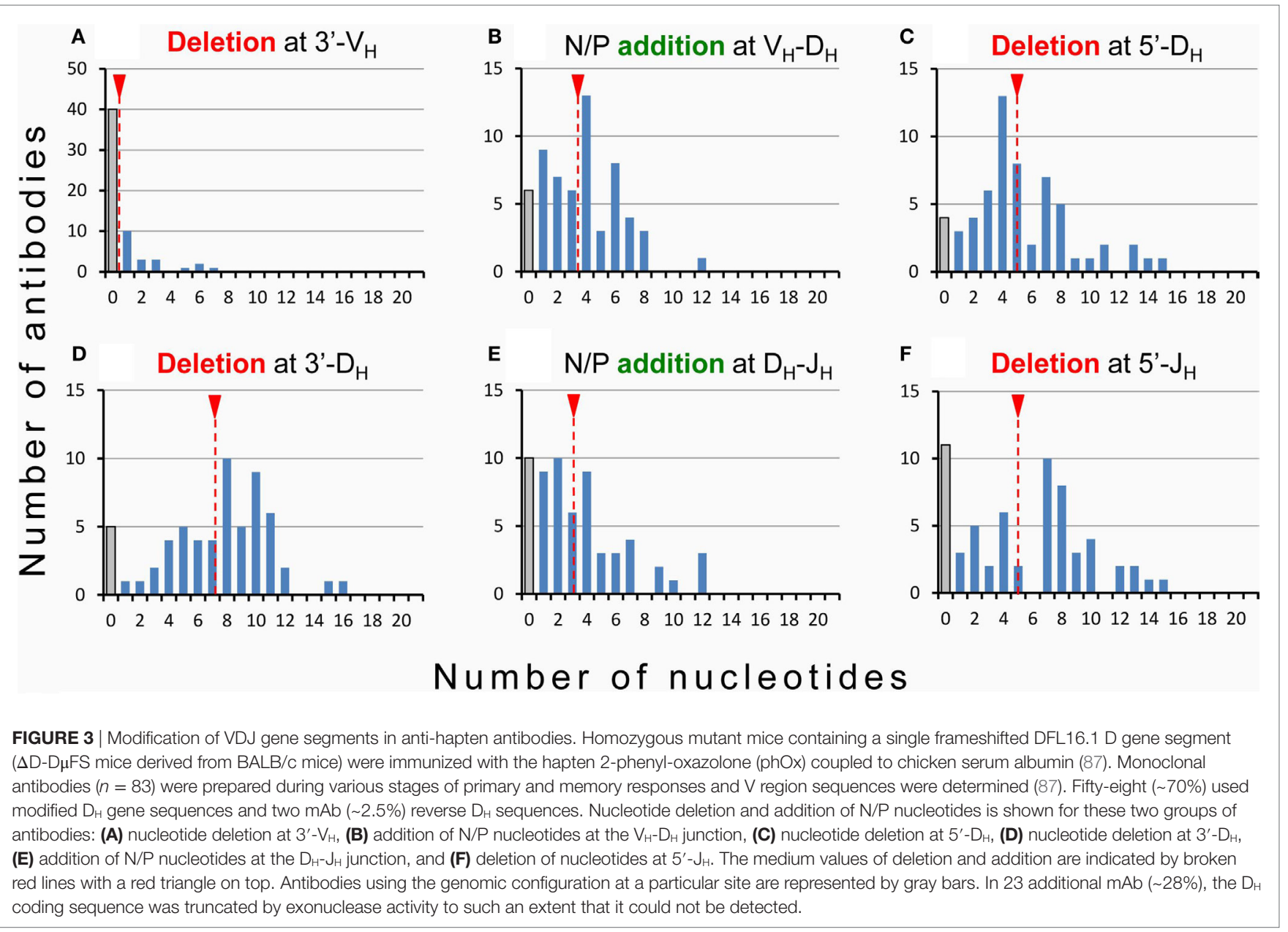

to B-2 cell antibodies, nAbs are produced and secreted by B-1 cells without stimulation by external antigens. B-1 cells are basically subdivided into CD5-expressing B-1a and CD5-negative B-1b cells (89) and their products of nAbs constitute a heterogeneous group of antibodies (94). Due to the lack of TdT in early ontogeny, sequences of $\mathrm{B}-1$ cell-derived $\mathrm{nAb}$ from fetal and neonatal mice do not or very rarely contain $\mathrm{N}$-nucleotides (90). However, this proportion increases with age so that two-thirds of adult B-1a transcripts contain $\mathrm{N}$-nucleotides and show a considerable CDR-H3 diversity (92). It has been argued that the fraction of $\mathrm{N}$-nucleotide-negative nAbs are therefore completely germline encoded (95). This conclusion, however, is challenged by sequences of neonatal nAbs (as well as $\left.\mathrm{TCR}_{\gamma / \delta}\right)$ that, although almost devoid of N-nucleotides, are not encoded by fully genomic VDJ combinations (90-92) since variable numbers of nucleotides are deleted from $3^{\prime}-\mathrm{V}_{\mathrm{H}}$, both sides of $\mathrm{D}_{\mathrm{H}}$ or $5^{\prime}-\mathrm{J}_{\mathrm{H}}$ sequences. Thus, as none of these $\mathrm{nAbs}$ and $\mathrm{TCR}_{\gamma / \delta}$ represents the full genomic information (90) it can be concluded that CDR3s of practically all BCR, $\mathrm{TCR}_{\alpha / \beta}$, and $\mathrm{TCR}_{\gamma / \delta}$ are somatically created and not fully derived from pure genomic sequences. This is related to the problem of self-nonself-discrimination which is certainly not determined in the genome but depends on genomically encoded translated products. Hence, with all likelihood, CDR3s of all antigen receptors belong to the nonself (Figure 4).
This is of fundamental importance for two reasons [reviewed in Ref. (58)]:

(1) Although generally ignored, there is multiple evidence that antigen-activated $\mathrm{B}$ and $\mathrm{T}$ cells not only present antigenpeptides on MHC molecules but also peptides of their own intrinsic antigen receptors which can be recognized by other anti-idiotypic $\mathrm{T}$ cell clones contained in the normal repertoire $(66,68,69,71,98-100)$.

(2) Various experimental investigations as well as clinical observations have clearly shown that CDR3-associated antigen receptor-intrinsic nonself-portions of non-mutated BCR and TCR represent the autologous clone-specific or idiotypic characters of antigen receptors. In BCR, in addition, new and thereby nonself-idiotopes are created and accumulate during TD immune responses by SHM $(84,101-109)$.

\section{IMMUNOGENICITY OF AUTOLOGOUS IDIOTOPES}

The question is now whether adaptive immune response-initiating BCR and TCR, because of their nonself-portions, are competent to 


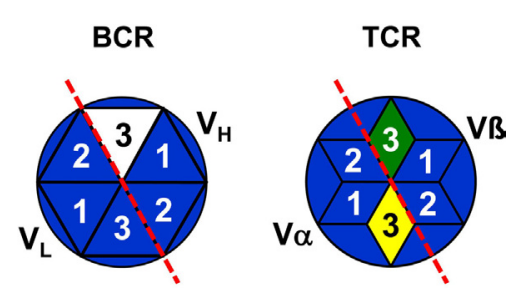

FIGURE 4 | Representation of B and T cells by top views of their antigen receptors. B cells are schematically represented by stylized top views of their BCR paratopes as hexagons [based on Ref. (96)] and T cells by hexagonal stars [based on Ref. (97)]. Numbers indicate the complementaritydetermining regions $1-3$ of $V_{H}, V_{L}, T_{C R}$, and TCR . BCR/TCR background colors symbolize the specificity of a particular paratope just as the genomic coding of CDR1 and CDR2. The full nonself-quality of CDR3s is indicated by different colors, but the marginal nonself-character of CDR-L3 is not shown.

induce anti-idiotypic responses by themselves as suggested in the idiotypic network theory $(7,57,110)$. Herein, Jerne supposed that, before any engagement in immune responses to foreign antigens, the size and state of activity of B (and T) cell clones is regulated by reactivity of their inherent idiotopes with other anti-idiotypic B (and T) cells contained in the system (27). Thus, the immune system was viewed as primarily self-centered and would strive in its entirety to reach a dynamic equilibrium of mutually interacting $\mathrm{B}$ and $\mathrm{T}$ cell clones. Jerne concluded that the antigen-free (AgF) immune system displays an "eigen"-behavior that results from idiotope-paratope interaction within the system and that "the invasion into our body of foreign particles, proteins, viruses, or bacteria, (which) incidentally disturb the dynamic harmony of the system" (7). However, this view did not remain uncontested. As the antigen-independent differentiation in the primary organs results in a unique cell, and not a clone of cells that can be activated by antigen as the CSL implies, Paul and Bona (111) argued that concentrations of idiotope and its corresponding anti-idiotypic paratope and their chance to encounter each other are too low to induce a functional connection. Hence, they argued that an idiotypic network that is endowed with an eigen-behavior does not exist before stimulation by antigen. The same conclusion can also be drawn from the following investigations. Since idiotopes represent $\mathrm{TD}$ antigens it has to be expected that such responses would lead to isotype-switched IgG anti-idiotypes. An answer to the question as to whether idiotopes are per se immunogenic can be deduced from studies of experimental animals whose microbial load is stepwise diminished. Compared to conventional mice the serum concentrations of all immunoglobulin classes except IgM is significantly lower in specific pathogen-free mice (112) and further decreased in germ-free (GF) mice (113) and virtually absent in AgF mice [reviewed in Ref. (114)]. Strikingly, the reduction of humoral immunoglobulins correlates with a severe impairment of many parameters of the innate immune system as well as the whole $\mathrm{T}$ cell compartment $(115,116)$. Consequently, numbers of $\mathrm{CD}^{+} \mathrm{T}$ cell subpopulations, $\mathrm{CD}^{+}$memory $\mathrm{T}$ cells, various innate lymphoid cells, blood cell gene expression patterns, resistance to infections, as well as humoral immunoglobulins have been found to increase to the state of conventional mice when such "clean" mice are re-infected with known collections or commensal microbes $(117,118)$. Thus, since sera of AgF mice are virtually devoid of IgG antibodies it can first be concluded that humoral IgG fully depends on stimulation by environmental antigens and second that antigen receptor-intrinsic nonself-portions are per se apparently non-immunogenic.

\section{EVIDENCE FOR PHYSIOLOGICAL IMPACT OF AUTOLOGOUS IDIOTOPES}

The idiotypic network theory does not include a clear distinction between the antibody's antigen combining site, the paratope, and its contained idiotope(s), and certain experiments were taken as evidence for a potential complete overlap between the combining site and binding of anti-idiotypes $(7,27)$. This led to the assumption that the shape of paratopes of particular anti-idiotypes represent internal images of the corresponding antigenic epitopes and that both BCR and TCR repertoires, therefore, contain internal images of all antigenic determinants of environmental antigens (see above) $(7,27)$. However, it is crucial to clearly discriminate between the dimension of BCR and TCR antigen combining sites that are formed by the six CDRs $(96,97)$ and the intrinsic nonselfidiotopes as BCR/TCR parts that are recognized by other antinonself $\mathrm{B}$ and $\mathrm{T}$ cells contained in both autologous repertoires, whereas reactivities of xenogeneic and allogeneic anti-idiotypes are misleading. Hence, the recognition that antigen receptorassociated nonself-portions constitute the idiotypic characters of BCR and TCR reject the view of internal image antibodies. Instead, "internal image" activity depends on idiotypic cross-reactivity so that anti-idiotypes may recognize idiotypes of completely different antigen-specificity (see above). These considerations document a clear and, at least in principle, facile explanation for idiotypic cascade-like chain reactions that are induced during antigeninduced immune responses, which contribute immunogenicity and adjuvanticity [reviewed in Ref. (58)]. This allows for a unification of clonal selection and idiotypic network theories, which hitherto are believed to be incompatible $(28,29)$. Hence, the recognition of antigen receptor-intrinsic nonself-portions as idiotypic characters prove that idiotypic regulation represents a physiological necessity. This view contributes to explain a variety of hitherto incomprehensible experimental findings:

(1) Contrary to the CSL, the immunization with many viruses, bacteria, and protein antigens not only leads to a specific response to these antigens but also simultaneously to a much higher increase of total immunoglobulins $(18,26,119)$. This immunization-associated polyclonal B cell activation is not only brought about by a variety of non-specifically acting factors including mitogens and cytokines that are secreted by activated T cells [discussed in Ref. (119)]. There are also indications that this polyclonal immunoglobulin production (including $\operatorname{IgG}$ ) is not totally antigen-non-specific since simultaneous immunization with two antigens demonstrated that each antigen induced its own specific and non-specific response, i.e., both effects were additive (120). This antigenrelated effect was supposed to be activated by a second BCRspecific and thus idiotype-specific helper mechanism (121).

(2) Although idiotypic nonself-portions of antigen receptors are per se non-immunogenic, as can be deduced from experiments 
in AgF animals (see above), autoantibody-masking and suppressing anti-idiotypic antibodies are frequently induced in healthy individuals containing a normal commensal microbial flora $(122,123)$.

(3) Although numerous FDA-approved therapeutic antibodies have successfully been used and seemingly never caused fatalities, but only mild infusion reactions that could easily be managed, it has also been reported that the clinical use of therapeutic antibodies of murine origin has been hampered because of occasionally severe side-effects that could be ascribed to their strong CDR-associated immunogenicity. Therefore, great efforts have been undertaken to reduce this immunogenicity by humanization and finally by use of human antibodies. However, in a certain percentage of patients, even fully human therapeutic antibodies may still produce pathological side effects through the induction of human anti-human antibodies $(124,125)$ that are directed at CDRs (126-128).

(4) Besides its secondary effector functions, humoral immunity can actively stimulate regulatory inductor functions [reviewed in Ref. (58)]. This is of particular importance for the transfer of the immunological experience of the mother to the newborn that aids the initial development of the nascent immune system and induces long-term effects (129). In various experimental systems, it has been demonstrated that immune as well as maternally derived monoclonal antibodies induce an immunological imprinting that alters the immune responses to the respective antigens for life-time $(130,131)$. Therefore, F1 and even F2 offspring of immunized dams cannot be regarded as "normal" mice when maternal antibodies are not any longer detectable. Importantly, these maternal effects can be induced with maternal antigenreactive antibodies (idiotypes) just as their corresponding antigen-non-reactive anti-idiotypes as demonstrated, for instance, for protection against microbial infections with respiratory syncytial virus (132) or group B streptococci (39).

Moreover, maternal antibodies selectively suppress $\operatorname{IgE}$ isotype responsiveness to antigens experienced by the mother (133). In an experimental model of food allergy to ovalbumin (OVA), the transgenerational IgE suppression by maternal OVA-containing immune-complexes (OVA-IC) conferred long-lasting protection against food anaphylaxis that was assumed to be mediated by OVA-specific Foxp $3^{+}$Tregs (134). However, this conclusion is questionable for three reasons. (i) The supposed OVA-specificity exclusively rests on the observation that Foxp $3^{+}$Tregs from mesenteric lymph nodes of offspring of OVA-sensitized dams proliferated stronger upon stimulation with OVA in vitro as compared to Tregs from non-sensitized dams or stimulation with peanut extract as irrelevant antigen. This conclusion would be valid if antigen stimulation would lead to exclusive activation of antigen-specific clones, as proposed in the CSL. This, however, is not the case because of the polyclonal nature of the response that includes the idiotypic chain reaction (see above). (ii) In addition, antigen-non-reactive suppressor $\mathrm{T}$ cells have been demonstrated in a similar experimental setting. Offspring of OVA-immunized female rats showed a transient suppression of IgG and IgM responses but a persistent OVA-specific IgE suppression, which was mediated by $\mathrm{CD}^{+}{ }^{+} \mathrm{CD} 4^{-} \mathrm{T}$ suppressor cells although these cells did not react with OVA (135). (iii) In the work of Ohsaki and co-workers (134), only maternally derived OVA-IC are taken into account thus emphasizing a central role of the antigen in mediating the transgenerational IgE suppression while a major functional impact of OVA-specific IgG antibody is not considered. However, this is necessary since it has been shown that a transgenerational suppression of IgE responsiveness to bee-venomphospholipase $\mathrm{A}_{2}\left(\mathrm{bvPLA}_{2}\right)$ allergen can also be achieved in a completely antigen-free experimental system with monoclonal antibodies (136). Maternally derived mAb not only suppress the parenteral IgE response to bvPLA $\mathrm{P}_{2}$ but also IgE responses that are induced by airway-immunization with nebulized ovomucoid-containing OVA (137). This suppression lasts until an age of 4 months but is not any longer detectable at 6 months. However, when IgE-inducing immunizations were started before an age of 4 months and continued in monthly intervals IgE suppression persisted for more than a year (137). This experimental finding is in line with considerations that early encounter of allergens might have a protective effect on later development of allergies $(134,138)$ which even may override a genetic predisposition $(137,139)$. In addition, in full agreement with the idiotypic chain reaction, even the postnatal transfer via colostrum and milk of a monoclonal anti-idiotypic mAb reactive with an IgG-anti-PLA $\mathrm{mAb}_{2}$ induced long-lasting IgE suppression while leaving the IgG response unaltered (140).

(5) An inductor function of antibodies has also been demonstrated in various experimental systems showing a mutually dependent development of both BCR and TCR repertoires. For instance, $\mathrm{B}$ cell-deficient mice exhibit a drastically reduced $\mathrm{T}$ cell repertoire the restoration of which could be achieved with immunoglobulin preparations or B cells in an Fc-independent manner (141, 142). Strikingly, this regeneration did not depend on the amount but on the diversity of the applied immunoglobulin and B cells. These observations acknowledge earlier studies, which had shown that the generation of B and $\mathrm{T}$ cell repertoires is mutually dependent (143-145).

(6) Interclonal idiotypic regulations among $\mathrm{B}$ and $\mathrm{T}$ cells are clearly visible during vaccination of autoimmune or malignant diseases with auto- or tumor-antigen-reactive T cells [ $\mathrm{T}$ cell vaccination (TCV)] $(146,147)$. In accordance with the idiotypic chain reaction, however, a successful TCV depends on the use of activated T cells, which not only induce anti-idiotypic responses to TCR CDR3 idiotopes but also anti-ergotypic responses, which are directed at activation markers of the inducing effector T cells irrespective of their TCR specificity (84). In addition, TCV-induced immunity needs the participation of B cells $(148,149)$. Effective TCV has been demonstrated in a variety of experimental animal models and clinical trials have provided promising results for the treatment of multiple sclerosis and have shown some clinical improvement in mild form of systemic lupus erythematosus (150).

Hence, immune responses in general induce subsequent idiotypic interclonal connections. These findings require 
reconsideration of the content of immunological memory, which is apparently not restricted to antigen-specific $\mathrm{B}$ and $\mathrm{T}$ cell clones but comprises a net of many idiotypically interconnected clones. Is it possible to correlate these idiotypic connections with current research into the regulation of adaptive immune responses?

\section{POST-INITIATIVE INVOLVEMENT OF IDIOTYPIC REGULATION OF IMMUNE RESPONSES}

Selection of clones with higher affinity (immune maturation) has long been assumed to be the main driving force for clonal progression during the immune response. In the $\mathrm{T}_{\mathrm{FH}}$ cell-depend GC response, somatically mutated B cells with the highest affinity are expected to preferentially concentrate and present antigen and thereby attract more help from $\mathrm{T}_{\mathrm{FH}}$ cells for further differentiation and clonal selection during class-switching. However, this simple scheme had to be modified since the amount as well as the activity of $\mathrm{T}_{\mathrm{FH}}$ cells also depends on a specialized type of follicular Foxp $3^{+}$ regulatory $\mathrm{T}$ cells $\left(\mathrm{T}_{\mathrm{FR}}\right)$ [reviewed in Ref. $(24,151)$ ]. Although $\mathrm{T}_{\mathrm{FR}}$ cells phenotypically resemble $\mathrm{T}_{\mathrm{FH}}$ and extrafollicular Tregs they constitute an own subpopulation that originates from thymic Foxp $3^{+}$precursors and limit numbers of $\mathrm{T}_{\mathrm{FH}}$ cells and GC antigenspecific as well as antigen-non-specific GC B cells (152). $\mathrm{T}_{\mathrm{FR}}$ cells inhibit GC reactions, affinity maturation just as plasma cell (PC) differentiation (153). Moreover, dampening of the GC reaction by Foxp $3^{+} \mathrm{T}_{\mathrm{FR}}$ cells reduces the amounts of secreted antigenspecific IgM, IgG1, IgG2b, and IgA (154). It is of interest that after immunization with the TD antigen sheep red blood cells (SRBC) splenic $\mathrm{T}_{\mathrm{FH}}$ and $\mathrm{T}_{\mathrm{FR}}$ cells (ratio $100: 16$ ) develop with different kinetics. Highest numbers of $\mathrm{T}_{\mathrm{FH}}$ are observed between days 7 and 11 while $\mathrm{T}_{\mathrm{FR}}$ cell numbers subsequently peak during days 11-17 (24). Since the SRBC-specific share of antibody-secreting cells in this response is only $\sim 10 \%$ compared to $\sim 90 \%$ of PCs secreting immunoglobulins of unknown specificities (121) it seems to be

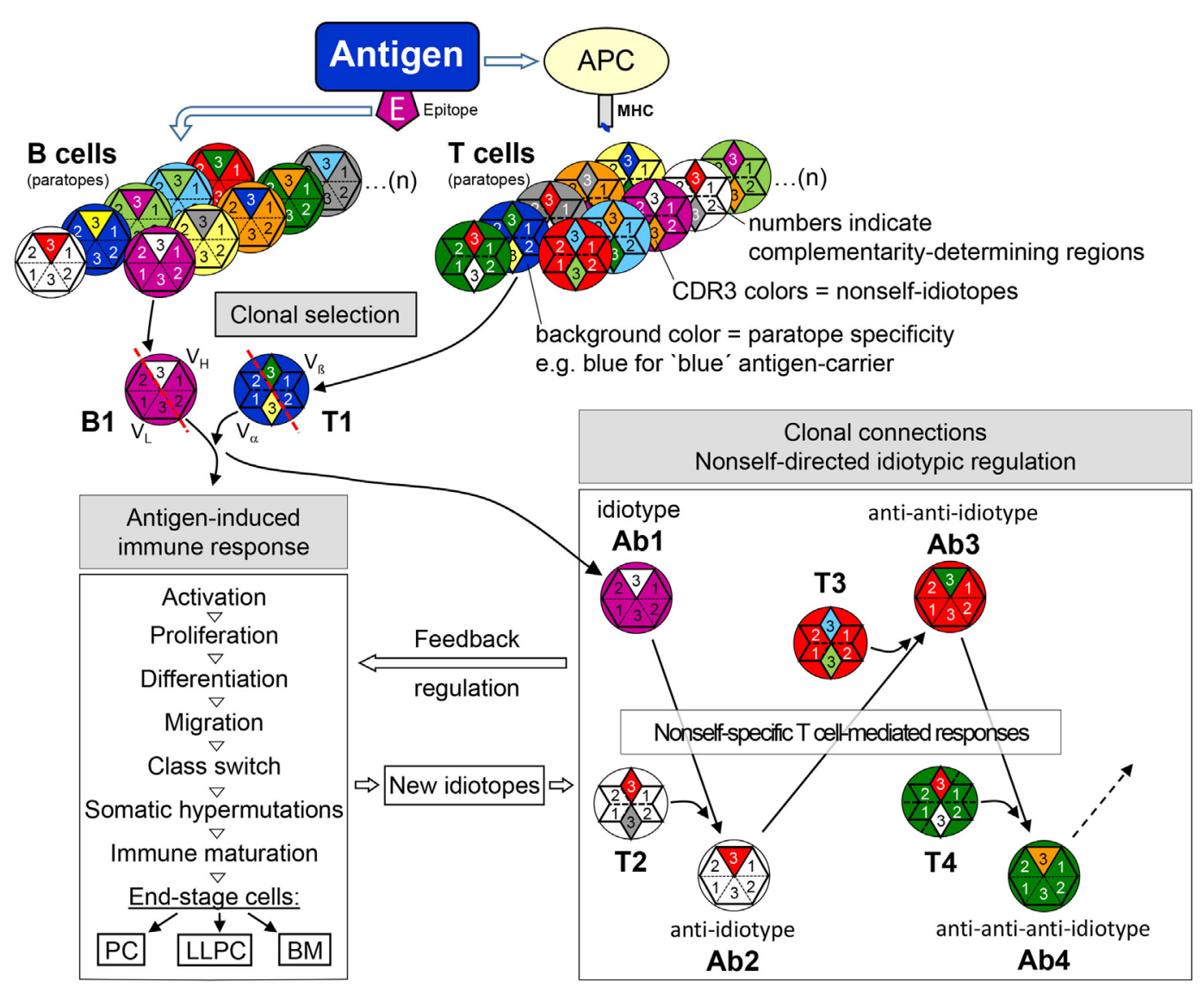

FIGURE 5 | The adaptive immune response-from clonal selection to nonself-directed idiotypic regulatory clonal connections. Antigen selects epitope-specific B cells and carrier-specific T cells from the respective repertoires. BCR/TCR background colors symbolize the specificity of a particular paratope (see legend to Figure 4), in this example, purple for the B cell epitope-specificity and blue for the carrier-specificity of T cells. After antigen-induced activation, CDR-H3 nonself-idiotopes (white) of antigen-specific idiotype (B1/Ab1 - purple paratope) activates nonself-specific anti-idiotypic B cells (Ab2-white paratope) with the help of likewise nonself-specific anti-idiotypic T cells (T1 - white paratope). In further reaction, nonself CDR-H3 portions of Ab2 (red) may be recognized and activate anti-anti-idiotypic B cells (Ab3-red paratope) with the help of Ab2-idiotype-specific T cells. This idiotypic cascade may proceed to anti-anti-anti-idiotypes (Ab4) and even further as shown for Ab6 (162). Thus, clonal selection and activation by antigen induces clonal connections of an idiotypic cascade that exerts a regulatory feedback on the ongoing antigen-induced response. During this response, in addition, somatic mutations create new nonself-idiotopes which may also induce an idiotypic feedback regulation. Abbreviations: APC, antigen-presenting cell; MHC, major histocompatibility complex; PC, plasma cell; LLPC, long-lived plasma cells; BM, B memory cell. 
conclusive that the involved $\mathrm{T}_{\mathrm{FH}}$ as well as $\mathrm{T}_{\mathrm{FR}}$ cells also represent heterogeneous populations with highly diverse repertoires. $\mathrm{T}_{\mathrm{FR}}$ cells may exert their regulatory function by direct cell-cell contacts with B and T cells (or indirectly via secreted cytokines) (24). A mechanism for this action, however, is not known and would probably rest on the determination of $\mathrm{T}_{\mathrm{FR}}$ specificities. As the idiotypic nonself-portions of all antigen receptors have hitherto not been taken into account it is tempting to speculate that components of the idiotypic cascade are at least part of the $\mathrm{T}_{\mathrm{FR}}$ repertoire.

Thus, are there direct indications that the GC response and in particular its regulation by $\mathrm{T}_{\mathrm{FR}}$ cells might depend on idiotypic interactions? Already during the heydays of research on idiotypic regulation, it was speculated that "a very dominant negative selection, perhaps against the idiotype of primary antibodies" might be involved in clonal progression during the immune response (155). Such an idiotype- resp. CDR-H3-directed regulation gained support by several later investigations demonstrating that other factors than affinity-selection must be involved [reviewed in Ref. (58)]. For instance, already 1 week after immunization the first GC memory cells, even when unmutated, express shorter idiotypic CDR3 in the $\mathrm{V}_{\mathrm{H}}$ region (CDR-H3) than antibody-secreting PCs and, by the end of the second week, most clones exhibiting affinity-enhancing mutations were also characterized by shorter CDR-H3 (156). A correlation between frequency of mutations and shorter lengths of CDR-H3 has also been observed in human antibodies $(157,158)$. In the murine model immune response to the hapten phOx the dominance of a particular idiotype $\left(\operatorname{Id}_{\mathrm{Ox} 1}\right)$ is $\mathrm{T}$ cell-dependent and first established during class-switch-recombination; concomitantly, CDR-H3 diversity is drastically reduced and accompanied with shortening and approximation of CDR-H3 lengths and with elimination of IgM-secreting clones despite their equal or even considerable higher affinities for the hapten than $\mathrm{Id}_{\mathrm{Ox} 1}$ antibodies (88). Thus, contrary to previous understanding, the $\mathrm{Id}_{\mathrm{Ox} 1}$ dominance does not seem to depend on its superior affinity but appears to be idiotypically selected. An idiotypic selection of slightly shorter and more uniform CDR-H3 lengths during class switching is also indicated in the response of C57BL/6 mice to the hapten NP $(88,159)$. Hence, these findings suggest the involvement of BCR-specific, namely idiotope-/CDR-H3-specific T cells during CSR and subsequent clonal selection in GCs.

Direct evidence for an idiotypic regulation has been provided in a murine adoptive transfer model showing that BCR peptidespecific (thus idiotype-specific but antigen non-reactive) $\mathrm{CD} 4^{+}$ $\mathrm{T}$ cells interrupt the GC reaction, inhibit the secondary response, and redirect the differentiation of B cells into extrafollicular plasmablasts (160). Furthermore, a TCR-idiotype-specific regulation of immune responses has also been demonstrated for $\mathrm{CD} 8^{+} \mathrm{T}$ cells that are restricted by the MHC class Ib molecule Qa-1 (HLA-E in humans), which is absent from naïve resting $\mathrm{CD} 4^{+} \mathrm{T}$ cells but transiently expressed after antigen activation (106). Blockade of this regulatory pathway in Qa-1-deficient mice leads to enhanced responses of $\mathrm{CD} 4^{+} \mathrm{T}$ cells to foreign as well as autoantigens (161).

\section{CONCLUDING REMARKS}

As receptors generally exert exclusive specificity for their genuine ligands it is taken for granted that BCR/TCR, because of their name "antigen receptors," exclusively bind antigens resp. MHC-presented antigenic peptides. It was almost regarded as a sacrilege that BCR/ TCR should perform meaningful reactions with other autologous anti-idiotypic antigen receptors. Thus, over time, the sole reactivity with antigens became a firmly established matter of course. The intrinsic reactivity with anti-idiotypic BCR/TCR did not make sense since it seemingly discredited the clear view that the immune system's task is the fight against microbial infections. This view, however, is not any longer tenable since idiotypic characters that are distinguishable in the autologous immune system are recognized as BCR/TCR nonself-portions in association with all CDR3s (but only slightly with that of the immunoglobulin L-chain) and somatic mutations in the variable regions of BCR that are generated during the adaptive immune response. As the self-nonself-discrimination is the fundamental question of all immunological research, immunology as a discipline has even been viewed as the science of self-nonself-discrimination. Hence, it is incomprehensible why CDR3 sequences although not encoded in the genome but somatically created and used as clonotypic markers, have not been recognized as idiotopes that belong to the nonself. Although foreign, these nonself-portions are non-immunogenic by themselves as can be concluded from experiments with AgF animals. However, antigen activation is the initial spark for clonal selection and cellular proliferation that is accompanied with an increase of antigen receptors plus their nonself-portions and expression of activation markers. Thereby, idiotypic (as well as ergotypic) characters become immunogenic and initiate further anti-idiotypic (and ergotypic) clonal connections that form a waning idiotypic chain reaction as schematically depicted in Figure 5. Hence, as proposed in the idiotypic network theory (7), the activation of adaptive immune responses is followed by regulatory idiotypic chain reactions. However, just as the idiotypic network theory by its own could not give a complete and satisfactory understanding of the adaptive immune response this cannot be expected from sole observance of the function and sequential expression of non-specific markers (lineage and activation markers, transcription factors, cytokines and their receptors). This can only be achieved by investigating the interdependency of clonotypic activation and idiotypic regulation both of which represent initializing regulatory principles that subsequently lead to expression of non-specific cellular markers and cytokine/chemokine secretion driving the differentiation of lymphocytes during antigen/autoantigen-induced immune responses. In conclusion, the well-documented fact of the autologous recognition of antigen receptor-intrinsic nonself parts as targets for idiotypic regulation of adaptive immune responses needs to be incorporated in future investigations.

\section{AUTHOR CONTRIBUTIONS}

The author confirms being the sole contributor of this work and approved it for publication.

\section{ACKNOWLEDGMENTS}

For stimulating discussions and helpful suggestions, I thank my colleague Stefan Rose-John. This work was supported by grants from the Deutsche Forschungsgemeinschaft. 


\section{REFERENCES}

1. Burnet FM. Clonal Selection Theory of Acquired Immunity. Cambridge, UK: Cambridge University Press (1959).

2. Smith KA. Toward a molecular understanding of adaptive immunity: a chronology, part I. Front Immunol (2012) 3:369. doi:10.3389/fimmu.2012.00369

3. Cohn M, Mitchison NA, Paul WE, Silverstein AM, Talmage DW, Weigert M. Reflections on the clonal-selection theory. Nat Rev Immunol (2007) 7(10): 823-30. doi:10.1038/nri2177

4. Murphy K. Janeway's Immunobiology. New York: Garland Science (2012).

5. Paul WE. Fundamental Immunology. 7th ed. Philadephia: Lippincott Williams \& Wilkins, a Wolters Kluwer business (2013).

6. Silverstein AM, Rose NR. There is only one immune system! The view from immunopathology. Semin Immunol (2000) 12(3):173-8; discussion 257-344. doi:10.1006/smim.2000.0228

7. Jerne NK. The generative grammar of the immune system. EMBO J (1985) 4(4):847-52.

8. Jerne NK. The natural-selection theory of antibody formation. Proc Natl Acad Sci U S A (1955) 41(11):849-57. doi:10.1073/pnas.41.11.849

9. Kohler H, Kaveri S, Kazatchkine M, Kieber-Emmons T. Natural selection theory revisited. Immunologist (2001) 8:91-3.

10. Kunicki MA, Amaya Hernandez LC, Davis KL, Bacchetta R, Roncarolo MG. Identity and diversity of human peripheral Th and T regulatory cells defined by single-cell mass cytometry. J Immunol (2017) 200:336-46. doi:10.4049/ jimmunol.1701025

11. Yu D, Vinuesa CG. The elusive identity of $\mathrm{T}$ follicular helper cells. Trends Immunol (2010) 31(10):377-83. doi:10.1016/j.it.2010.07.001

12. Shlomchik MJ, Weisel F. Germinal center selection and the development of memory B and plasma cells. Immunol Rev (2012) 247(1):52-63. doi:10.1111/ j.1600-065X.2012.01124.x

13. Zotos D, Tarlinton DM. Determining germinal centre B cell fate. Trends Immunol (2012) 33(6):281-8. doi:10.1016/j.it.2012.04.003

14. Mesin L, Ersching J, Victora GD. Germinal center B cell dynamics. Immunity (2016) 45(3):471-82. doi:10.1016/j.immuni.2016.09.001

15. Vinuesa CG, Linterman MA, Yu D, MacLennan IC. Follicular helper T cells. Annu Rev Immunol (2016) 34:335-68. doi:10.1146/annurev-immunol-041015055605

16. Pape KA, Taylor JJ, Maul RW, Gearhart PJ, Jenkins MK. Different B cell populations mediate early and late memory during an endogenous immune response. Science (2011) 331(6021):1203-7. doi:10.1126/science.1201730

17. Radbruch A, Muehlinghaus G, Luger EO, Inamine A, Smith KG, Dorner T, et al. Competence and competition: the challenge of becoming a long-lived plasma cell. Nat Rev Immunol (2006) 6(10):741-50. doi:10.1038/nri1886

18. Di Niro R, Lee SJ, Vander Heiden JA, Elsner RA, Trivedi N, Bannock JM, et al. Salmonella infection drives promiscuous B cell activation followed by extrafollicular affinity maturation. Immunity (2015) 43(1):120-31. doi:10.1016/j. immuni.2015.06.013

19. Takemori T, Kaji T, Takahashi Y, Shimoda M, Rajewsky K. Generation of memory B cells inside and outside germinal centers. Eur J Immunol (2014) 44(5):1258-64. doi:10.1002/eji.201343716

20. Dogan I, Bertocci B, Vilmont V, Delbos F, Megret J, Storck S, et al. Multiple layers of B cell memory with different effector functions. Nat Immunol (2009) 10(12):1292-9. doi:10.1038/ni.1814

21. Zhang J, Liu YJ, MacLennan IC, Gray D, Lane PJ. B cell memory to thymusindependent antigens type 1 and type 2: the role of lipopolysaccharide in B memory induction. Eur J Immunol (1988) 18(9):1417-24. doi:10.1002/ eji.1830180918

22. Obukhanych TV, Nussenzweig MC. T-independent type II immune responses generate memory B cells. J Exp Med (2006) 203(2):305-10. doi:10.1084/ jem.20052036

23. Lange H, Zemlin M, Tanasa RI, Trad A, Weiss T, Menning H, et al. Thymusindependent type 2 antigen induces a long-term IgG-related network memory. Mol Immunol (2008) 45(10):2847-60. doi:10.1016/j.molimm.2008.01.020

24. Vanderleyden I, Linterman MA, Smith KG. Regulatory T cells and control of the germinal centre response. Arthritis Res Ther (2014) 16(5):471. doi:10.1186/s13075-014-0471-7

25. Tas JM, Mesin L, Pasqual G, Targ S, Jacobsen JT, Mano YM, et al. Visualizing antibody affinity maturation in germinal centers. Science (2016) 351(6277):1048-54. doi:10.1126/science.aad3439
26. Kuraoka M, Schmidt AG, Nojima T, Feng F, Watanabe A, Kitamura D, et al. Complex antigens drive permissive clonal selection in germinal centers. Immunity (2016) 44(3):542-52. doi:10.1016/j.immuni.2016.02.010

27. Jerne NK. Towards a network theory of the immune system. Ann Immunol (Paris) (1974) 125C(1-2):373-89.

28. Cohn M. The wisdom of hindsight. Annu Rev Immunol (1994) 12:1-62. doi:10.1146/annurev.iy.12.040194.000245

29. Eichmann K. The Network Collective - Rise and Fall of a Scientific Paradigm. Basel, Switzerland: Birkhäuser (2008).

30. Kieber-Emmons T, Monzavi-Karbassi B, Pashov A, Saha S, Murali R, Kohler H. The promise of the anti-idiotype concept. Front Oncol (2012) 2:196. doi: $10.3389 /$ fonc. 2012.00196

31. Oudin J, Michel M. Une nuovelle forme d'allotypie des globulines du serum de lapin, apparement liée à la function et à la spécifité des anticorps. CR Acad Sci (Paris) (1963) 257:805-8.

32. Kunkel HG, Mannik M, Williams RC. Individual antigenic specificities of isolated antibodies. Science (1963) 140:1218-9. doi:10.1126/science.140. 3572.1218

33. Bona C. Anti-idiotypes. In: Shoenfeld Y, Kennedy RC, Ferrone S, editors. Idiotypes in Medicine: Autoimmunity, Infection and Cancer. Amsterdam: Elsevier (1997). p. 11-8.

34. Sege K, Peterson PA. Use of anti-idiotypic antibodies as cell-surface receptor probes.ProcNatlAcadSciUSA (1978) 75(5):2443-7.doi:10.1073/pnas.75.5.2443

35. Nisonoff A, Lamoyi E. Implications of the presence of an internal image of the antigen in anti-idiotypic antibodies: possible application to vaccine production. Clin Immunol Immunopathol (1981) 21(3):397-406. doi:10.1016/ 0090-1229(81)90228-2

36. Nisonoff A. Idiotypes: concepts and applications. J Immunol (1991) 147(8): 2429-38.

37. Fields BA, Goldbaum FA, Ysern X, Poljak RJ, Mariuzza RA. Molecular basis of antigen mimicry by an anti-idiotope. Nature (1995) 374(6524):739-42. doi: $10.1038 / 374739 \mathrm{a} 0$

38. Schreiber JR, Patawaran M, Tosi M, Lennon J, Pier GB. Anti-idiotypeinduced, lipopolysaccharide-specific antibody response to Pseudomonas aeruginosa. J Immunol (1990) 144(3):1023-9.

39. Magliani W, Polonelli L, Conti S, Salati A, Rocca PF, Cusumano V, et al. Neonatal mouse immunity against group B streptococcal infection by maternal vaccination with recombinant anti-idiotypes. Nat Med (1998) 4(6):705-9. doi:10.1038/nm0698-705

40. Kohler H, Kieber-Emmons T, Srinivasan S, Kaveri S, Morrow WJ, Muller S, et al. Revised immune network concepts. Clin Immunol Immunopathol (1989) 52(1):104-16. doi:10.1016/0090-1229(89)90197-9

41. Bona CA, Finley S, Waters S, Kunkel HG. Anti-immunoglobulin antibodies. III. Properties of sequential anti-idiotypic antibodies to heterologous antigamma globulins. Detection of reactivity of anti-idiotype antibodies with epitopes of Fc fragments (homobodies) and with epitopes and idiotopes (epibodies). J Exp Med (1982) 156(4):986-99.

42. Kang CY, Brunck TK, Kieber-Emmons T, Blalock JE, Kohler H. Inhibition of self-binding antibodies (autobodies) by a VH-derived peptide. Science (1988) 240(4855):1034-6. doi:10.1126/science.3368787

43. Kang CY, Kohler H. Immunoglobulin with complementary paratope and idiotope. J Exp Med (1986) 163(4):787-96. doi:10.1084/jem.163.4.787

44. Fougereau M, Schiff C. Breaking the first circle. Immunol Rev (1988) 105:69-84. doi:10.1111/j.1600-065X.1988.tb00766.x

45. Hornbeck PV, Lewis GK. Idiotype connectance in the immune system. I. Expression of a cross-reactive idiotype on induced anti-p-azophenylarsonate antibodies and on endogenous antibodies not specific for arsonate. J Exp Med (1983) 157(4):1116-36. doi:10.1084/jem.157.4.1116

46. Oudin J, Cazenave PA. Similar idiotypic specificities in immunoglobulin fractions with different antibody functions or even without detectable antibody function. Proc Natl Acad Sci U S A (1971) 68(10):2616-20. doi:10.1073/ pnas.68.10.2616

47. Marion TN, Dzierzak EA, Lee HS, Adams RL, Janeway CA Jr. Nondinitrophenyl-binding immunoglobulin that bears a dominant idiotype (Id460) associated with antidinitrophenyl antibody is specific for an antigen on Pasteurella pneumotropica. J Exp Med (1984) 159(1):221-33. doi:10.1084/ jem.159.1.221

48. Zaghouani H, Stanislawski M. Regulation of the response to alpha(1-3) dextran: an anti-dextran associated idiotope of $\mathrm{BALB} / \mathrm{c}$ mice is also expressed on 
A/J anti-NIP antibodies. Mol Immunol (1987) 24(12):1237-42. doi:10.1016/ 0161-5890(87)90117-9

49. Zaghouani H, Bonilla FA, Meek K, Bona C. Molecular basis for expression of the A48 regulatory idiotope on antibodies encoded by immunoglobulin variable-region genes from various families. Proc Natl Acad Sci U S A (1989) 86(7):2341-5. doi:10.1073/pnas.86.7.2341

50. Migliorini P, Ardman B, Kaburaki J, Schwartz RS. Parallel sets of autoantibodies in MRL-lpr/lpr mice. An anti-DNA, anti-SmRNP, anti-gp70 network. J Exp Med (1987) 165(2):483-99. doi:10.1084/jem.165.2.483

51. Urbain J, Wikler M, Franssen JD, Collignon C. Idiotypic regulation of the immune system by the induction of antibodies against anti-idiotypic antibodies. Proc Natl Acad Sci U S A (1977) 74(11):5126-30. doi:10.1073/ pnas.74.11.5126

52. Bona CA, Heber-Katz E, Paul WE. Idiotype-anti-idiotype regulation. I. Immunization with a levan-binding myeloma protein leads to the appearance of auto-anti-(anti-idiotype) antibodies and to the activation of silent clones. J Exp Med (1981) 153(4):951-67. doi:10.1084/jem.153.4.951

53. Fagerberg J, Hjelm AL, Ragnhammar P, Frodin JE, Wigzell H, Mellstedt H. Tumor regression in monoclonal antibody-treated patients correlates with the presence of anti-idiotype-reactive T lymphocytes. Cancer Res (1995) 55(9):1824-7.

54. Lopez-Requena A, Burrone OR, Cesco-Gaspere M. Idiotypes as immunogens: facing the challenge of inducing strong therapeutic immune responses against the variable region of immunoglobulins. Front Oncol (2012) 2:159. doi:10.3389/fonc.2012.00159

55. Coscia M, Kwak LW. Therapeutic idiotype vaccines in B lymphoproliferative diseases. Expert Opin Biol Ther (2004) 4(6):959-63. doi:10.1517/ 14712598.4.6.959

56. Bendandi M. Idiotype vaccines for lymphoma: proof-of-principles and clinical trial failures. Nat Rev Cancer (2009) 9(9):675-81. doi:10.1038/nrc2717

57. Coutinho A. The network theory: 21 years later [editorial]. Scand J Immunol (1995) 42(1):3-8. doi:10.1111/j.1365-3083.1995.tb03619.x

58. Lemke H. Antigen receptor-intrinsic non-self: the key to understanding regulatorylymphocyte-mediated idiotypic control of adaptive immune responses. Crit Rev Immunol (2016) 36(1):13-56. doi:10.1615/CritRevImmunol.2016016606

59. Rajewsky K. Years in Cologne. Annu Rev Immunol (2013) 31:1-29. doi:10.1146/annurev.immunol.021908.132646

60. Binz H, Wigzell $\mathrm{H}$. Shared idiotypic determinants on B and T lymphocytes reactive against the same antigenic determinants. I. Demonstration of similar or identical idiotypes on IgG molecules and T-cell receptors with specificity for the same alloantigens. J Exp Med (1975) 142(1):197-211. doi:10.1084/ jem.142.1.197

61. Binz H, Wigzell H, Bazin H. T-cell idiotypes are linked to immunoglobulin heavy chain genes. Nature (1976) 264(5587):639-42. doi:10.1038/264639a0

62. Rajewsky K. Cross-reacting idiotypes on antibodies and $\mathrm{T}$ cell receptors: how can the data be interpreted? Scand J Immunol (1983) 18:95-6. doi:10.1111/ j.1365-3083.1983.tb00844.x

63. Martinez C, Bragado R, de la Hera A, Toribio ML, Marcos MA, Bandeira A, et al. Functional and biochemical evidence for the recognition of $\mathrm{T}$ cell receptors by monoclonal antibodies to an immunoglobulin idiotype. J Mol Cell Immunol (1986) 2(6):307-13.

64. Bogen B, Weiss S. Processing and presentation of idiotypes to MHC-restricted Tcells.IntRevImmunol(1993) 10(4):337-55.doi:10.3109/08830189309061709

65. Zaghouani H, Steinman R, Nonacs R, Shah H, Gerhard W, Bona C. Presentation of a viral T cell epitope expressed in the CDR3 region of a self immunoglobulin molecule. Science (1993) 259(5092):224-7. doi:10.1126/ science.7678469

66. Rudensky AY, Mazel SM, Blechman JM, Yurin VL. Immunoglobulin-specific T-B cell interaction. IV. B cell presentation of idiotypic determinant(s) of monoclonal anti-surface immunoglobulin antibody to idiotope-recognizing helper T clones. Eur J Immunol (1990) 20(8):1691-6. doi:10.1002/eji.1830201012

67. Mitra-Kaushik S, Shaila MS, Karande AK, Nayak R. Idiotype and antigen-specific $\mathrm{T}$ cell responses in mice on immunization with antigen, antibody, and anti-idiotypic antibody. Cell Immunol (2001) 209(2):109-19. doi:10.1006/ cimm.2001.1794

68. Munthe LA, Os A, Zangani M, Bogen B. MHC-restricted Ig V regiondriven T-B lymphocyte collaboration: B cell receptor ligation facilitates switch to IgG production. J Immunol (2004) 172(12):7476-84. doi:10.4049/ jimmunol.172.12.7476
69. Jacobsen J, Haabeth OA, Tveita AA, Schjetne KW, Munthe LA, Bogen B. Naive idiotope-specific B and T cells collaborate efficiently in the absence of dendritic cells. J Immunol (2014) 192(9):4174-83. doi:10.4049/jimmunol. 1302359

70. Elias D, Tikochinski Y, Frankel G, Cohen IR. Regulation of NOD mouse autoimmune diabetes by $\mathrm{T}$ cells that recognize a TCR CDR3 peptide. Int Immunol (1999) 11(6):957-66. doi:10.1093/intimm/11.6.957

71. Lal G, Shaila MS, Nayak R. Activated mouse T cells downregulate, process and present their surface TCR to cognate anti-idiotypic CD4+ T cells. Immunol Cell Biol (2006) 84(2):145-53. doi:10.1111/j.1440-1711.2005.01405.x

72. Kluskens L, Kohler H. Regulation of immune response by autogenous antibody against receptor. Proc Natl Acad Sci U S A (1974) 71(12):5083-7. doi:10.1073/pnas.71.12.5083

73. Cosenza H. Detection of anti-idiotype reactive cells in the response to phosphorylcholine. Eur J Immunol (1976) 6(2):114-6. doi:10.1002/eji.1830060208

74. Lemke H, Lange H. Generalization of single immunological experiences by idiotypically mediated clonal connections. Adv Immunol (2002) 80:203-41. doi:10.1016/S0065-2776(02)80016-5

75. Jung D, Alt FW. Unraveling V(D)J recombination; insights into gene regulation. Cell (2004) 116(2):299-311. doi:10.1016/S0092-8674(04)00039-X

76. Davis MM, Bjorkman PJ. T-cell antigen receptor genes and T-cell recognition. Nature (1988) 334(6181):395-402. doi:10.1038/334395a0

77. Early P, Huang H, Davis M, Calame K, Hood L. An immunoglobulin heavy chain variable region gene is generated from three segments of DNA: VH, D and JH. Cell (1980) 19(4):981-92.

78. Schilling J, Clevinger B, Davie JM, Hood L. Amino acid sequence of homogeneous antibodies to dextran and DNA rearrangements in heavy chain V-region gene segments. Nature (1980) 283(5742):35-40. doi:10.1038/283035a0

79. Alt FW, Baltimore D. Joining of immunoglobulin heavy chain gene segments: implications from a chromosome with evidence of three D-JH fusions. Proc Natl Acad Sci U S A (1982) 79(13):4118-22. doi:10.1073/pnas.79.13.4118

80. Lafaille JJ, DeCloux A, Bonneville M, Takagaki Y, Tonegawa S. Junctional sequences of $\mathrm{T}$ cell receptor gamma delta genes: implications for gamma delta $\mathrm{T}$ cell lineages and for a novel intermediate of V-(D)-J joining. Cell (1989) 59(5):859-70. doi:10.1016/0092-8674(89)90609-0

81. Gilfillan S, Dierich A, Lemeur M, Benoist C, Mathis D. Mice lacking TdT: mature animals with an immature lymphocyte repertoire. Science (1993) 261(5125):1175-8. doi:10.1126/science.8356452

82. Komori T, Okada A, Stewart V, Alt FW. Lack of $\mathrm{N}$ regions in antigen receptor variable region genes of TdT-deficient lymphocytes. Science (1993) 261(5125):1171-5. doi:10.1126/science.8356451

83. Cabaniols JP, Fazilleau N, Casrouge A, Kourilsky P, Kanellopoulos JM. Most alpha/beta $\mathrm{T}$ cell receptor diversity is due to terminal deoxynucleotidyl transferase. J Exp Med (2001) 194(9):1385-90. doi:10.1084/jem.194.9.1385

84. Cohen IR, Quintana FJ, Mimran A. Tregs in T cell vaccination: exploring the regulation of regulation. J Clin Invest (2004) 114(9):1227-32. doi:10.1172/ JCI200423396

85. Garcia KC, Adams EJ. How the T cell receptor sees antigen - a structural view. Cell (2005) 122(3):333-6. doi:10.1016/j.cell.2005.07.015

86. Berek C, Milstein C. Mutation drift and repertoire shift in the maturation of the immune response. Immunol Rev (1987) 96:23-41. doi:10.1111/j.1600065X.1987.tb00507.x

87. Trad A, Tanasa RI, Lange H, Zemlin M, Schroeder HW Jr, Lemke H. Clonal progression during the $\mathrm{T}$ cell-dependent $\mathrm{B}$ cell antibody response depends on the immunoglobulin DH gene segment repertoire. Front Immunol (2014) 5:385. doi:10.3389/fimmu.2014.00385

88. Lange H, Hecht O, Zemlin M, Trad A, Tanasa RI, Schroeder HW Jr, et al. Immunoglobulin class switching appears to be regulated by B-cell antigen receptor-specific T-cell action. Eur J Immunol (2012) 42(4):1016-29. doi:10.1002/eji.201141857

89. Kantor AB, Stall AM, Adams S, Herzenberg LA, Herzenberg LA. Differential development of progenitor activity for three B-cell lineages. Proc Natl Acad Sci U S A (1992) 89(8):3320-4. doi:10.1073/pnas.89.8.3320

90. Feeney AJ. Lack of $\mathrm{N}$ regions in fetal and neonatal mouse immunoglobulin V-D-J junctional sequences. J Exp Med (1990) 172(5):1377-90. doi:10.1084/ jem.172.5.1377

91. Tornberg UC, Holmberg D. B-1a, B-1b and B-2 B cells display unique VHDJH repertoires formed at different stages of ontogeny and under different selection pressures. EMBO J (1995) 14(8):1680-9. 
92. Kantor AB, Merrill CE, Herzenberg LA, Hillson JL. An unbiased analysis of $\mathrm{V}(\mathrm{H})-\mathrm{D}-\mathrm{J}(\mathrm{H})$ sequences from B-1a, B-1b, and conventional B cells. J Immunol (1997) 158(3):1175-86.

93. Berek C, Griffiths GM, Milstein C. Molecular events during maturation of the immune response to oxazolone. Nature (1985) 316(6027):412-8. doi: $10.1038 / 316412 \mathrm{a} 0$

94. Holodick NE, Rodriguez-Zhurbenko N, Hernandez AM. Defining natural antibodies. Front Immunol (2017) 8:872. doi:10.3389/fimmu.2017.00872

95. Vale AM, Cavazzoni CB, Nobrega A, Schroeder HW Jr. The global self-reactivity profile of the natural antibody repertoire is largely independent of germline DH sequence. Front Immunol (2016) 7:296. doi:10.3389/fimmu. 2016.00296

96. Collis AV, Brouwer AP, Martin AC. Analysis of the antigen combining site: correlations between length and sequence composition of the hypervariable loops and the nature of the antigen. J Mol Biol (2003) 325(2):337-54. doi:10.1016/S0022-2836(02)01222-6

97. Garcia KC, Degano M, Stanfield RL, Brunmark A, Jackson MR, Peterson PA, et al. An alphabeta $\mathrm{T}$ cell receptor structure at $2.5 \mathrm{~A}$ and its orientation in the TCR-MHC complex. Science (1996) 274(5285):209-19. doi:10.1126/ science.274.5285.209

98. Bogen B, Malissen B, Haas W. Idiotope-specific T cell clones that recognize syngeneic immunoglobulin fragments in the context of class II molecules. Eur J Immunol (1986) 16(11):1373-8. doi:10.1002/eji.1830161110

99. Weiss S, Bogen B. MHC class II-restricted presentation of intracellular antigen. Cell (1991) 64(4):767-76. doi:10.1016/0092-8674(91)90506-T

100. Jacobsen JT, Lunde E, Sundvold-Gjerstad V, Munthe LA, Bogen B. The cellular mechanism by which complementary Id+ and anti-Id antibodies communicate: T cells integrated into idiotypic regulation. Immunol Cell Biol (2010) 88(5):515-22. doi:10.1038/icb.2009.118

101. Wen YJ, Lim SH. T cells recognize the VH complementarity-determining region 3 of the idiotypic protein of B cell non-Hodgkin's lymphoma. Eur J Immunol (1997) 27(4):1043-7. doi:10.1002/eji.1830270435

102. Pollok BA, Kearney JF. Identification and characterization of an apparent germline set of auto-anti-idiotypic regulatory B lymphocytes. J Immunol (1984) 132(1):114-21.

103. Pollok BA, Kearney JF, Vakil M, Perry RP. A biological consequence of variation in the site of D-JH gene rearrangement. Nature (1984) 311(5984):376-9. doi:10.1038/311376a0

104. Eyerman MC, Wysocki L. T cell recognition of somatically-generated Ab diversity. J Immunol (1994) 152(4):1569-77.

105. Fagerberg J, Yi Q, Gigliotti D, Harmenberg U, Ruden U, Persson B, et al. T-cell-epitope mapping of the idiotypic monoclonal IgG heavy and light chains in multiple myeloma. Int J Cancer (1999) 80(5):671-80. doi:10.1002/ (SICI) 1097-0215(19990301)80:5<671::AID-IJC7>3.0.CO;2-E

106. Jiang H, Chess L. The specific regulation of immune responses by CD8+ $\mathrm{T}$ cells restricted by the MHC class Ib molecule, Qa-1. Annu Rev Immunol (2000) 18:185-216. doi:10.1146/annurev.immunol.18.1.185

107. Lal G, Shaila MS, Nayak R. Booster immunization of antigen primed mice with anti-idiotypic $\mathrm{T}$ cells generates antigen-specific memory $\mathrm{T}$ cell response. Vaccine (2006) 24(8):1149-58. doi:10.1016/j.vaccine.2005.08.099

108. Zang YC, Hong J, Rivera VM, Killian J, Zhang JZ. Preferential recognition of TCR hypervariable regions by human anti-idiotypic T cells induced by T cell vaccination. J Immunol (2000) 164(8):4011-7. doi:10.4049/jimmunol. 164.8.4011

109. Lider O, Reshef T, Beraud E, Ben-Nun A, Cohen IR. Anti-idiotypic network induced by $\mathrm{T}$ cell vaccination against experimental autoimmune encephalomyelitis. Science (1988) 239(4836):181-3. doi:10.1126/science.2447648

110. Coutinho A, Forni L, Holmberg D, Ivars F, Vaz N. From an antigen-centered, clonal perspective of immune responses to an organism-centered, network perspective of autonomous activity in a self-referential immune system. Immunol Rev (1984) 79:151-68. doi:10.1111/j.1600-065X.1984.tb00492.x

111. Paul WE, Bona C. Regulatory idiotopes and immune networks: a hypothesis. Immunol Today (1982) 3(9):230-4. doi:10.1016/0167-5699(82)90006-8

112. Horsfall DJ, Cooper JM, Rowley D. Changes in the immunoglobulin levels of the mouse gut and serum during conventionalisation and following administration of Salmonella typhimurium. Aust J Exp Biol Med Sci (1978) 56(6):727-35. doi:10.1038/icb.1978.79

113. Hashimoto K, Handa H, Umehara K, Sasaki S. Germfree mice reared on an "antigen-free" diet. Lab Anim Sci (1978) 28(1):38-45.
114. Wostmann B. Germ-free and gnotobiotic animal models. In: Melby ECJ, Altman NH, editors. Handbook of Laboratory Animal Science. Cleveland: CRC Press (1996). p. 116-9.

115. Geuking MB, Cahenzli J, Lawson MA, Ng DC, Slack E, Hapfelmeier S, et al. Intestinal bacterial colonization induces mutualistic regulatory $\mathrm{T}$ cell responses. Immunity (2011) 34(5):794-806. doi:10.1016/j.immuni. 2011.03.021

116. Hooper LV, Littman DR, Macpherson AJ. Interactions between the microbiota and the immune system. Science (2012) 336(6086):1268-73. doi:10.1126/ science. 1223490

117. Beura LK, Hamilton SE, Bi K, Schenkel JM, Odumade OA, Casey KA, et al. Normalizing the environment recapitulates adult human immune traits in laboratory mice. Nature (2016) 532(7600):512-6. doi:10.1038/nature17655

118. Masopust D, Sivula CP, Jameson SC. Of mice, dirty mice, and men: using mice to understand human immunology. J Immunol (2017) 199(2):383-8. doi:10.4049/jimmunol.1700453

119. Silverstein AM, Rose NR. On the implications of polyclonal B cell activation. Nat Immunol (2003) 4(10):931-2; author reply 2. doi:10.1038/ni1003-931

120. Urbain-Vansanten G. Concomitant synthesis, in separate cells, of non-reactive immunoglobulins and specific antibodies after immunization with tobacco mosaic virus. Immunology (1970) 19(5):783-97.

121. Rosenberg YJ, Chiller JM. Ability of antigen-specific helper cells to effect a class-restricted increase in total Ig-secreting cells in spleens after immunization with the antigen. J Exp Med (1979) 150(3):517-30. doi:10.1084/ jem.150.3.517

122. Oak S, Gilliam LK, Landin-Olsson M, Torn C, Kockum I, Pennington CR, et al. The lack of anti-idiotypic antibodies, not the presence of the corresponding autoantibodies to glutamate decarboxylase, defines type 1 diabetes. Proc Natl Acad Sci U S A (2008) 105(14):5471-6. doi:10.1073/pnas.0800578105

123. Cui Z, Zhao MH, Segelmark M, Hellmark T. Natural autoantibodies to myeloperoxidase, proteinase 3 , and the glomerular basement membrane are present in normal individuals. Kidney Int (2010) 78(6):590-7. doi:10.1038/ ki.2010.198

124. Kalden JR, Schulze-Koops H. Immunogenicity and loss of response to TNF inhibitors: implications for rheumatoid arthritis treatment. Nat Rev Rheumatol (2017) 13(12):707-18. doi:10.1038/nrrheum.2017.187

125. Garces S, Demengeot J. The immunogenicity of biologic therapies. Curr Probl Dermatol (2018) 53:37-48. doi:10.1159/000478077

126. Harding FA, Stickler MM, Razo J, DuBridge RB. The immunogenicity of humanized and fully human antibodies: residual immunogenicity resides in the CDR regions. MAbs (2010) 2(3):256-65. doi:10.4161/mabs.2.3.11641

127. Hall B, Kiely C, Tobin AM, McNamara D. HAHA antibodies - not such a funny story. J Crohns Colitis (2014) 8(5):439-40. doi:10.1016/j.crohns.2013. 11.018

128. Nechansky A. HAHA - nothing to laugh about. Measuring the immunogenicity (human anti-human antibody response) induced by humanized monoclonal antibodies applying ELISA and SPR technology. J Pharm Biomed Anal (2010) 51(1):252-4. doi:10.1016/j.jpba.2009.07.013

129. Lemke H, Coutinho A, Lange H. Lamarckian inheritance by somatically acquired maternal IgG phenotypes. Trends Immunol (2004) 25(4):180-6. doi:10.1016/j.it.2004.02.007

130. Lemke H, Lange $H$, Berek C. Maternal immunization modulates the primary immune response to 2-phenyl-oxazolone in $\mathrm{BALB} / \mathrm{c}$ mice. Eur J Immunol (1994) 24(12):3025-30. doi:10.1002/eji.1830241216

131. Fink K, Zellweger R, Weber J, Manjarrez-Orduno N, Holdener M, Senn BM, et al. Long-term maternal imprinting of the specific B cell repertoire by maternal antibodies. Eur J Immunol (2008) 38(1):90-101. doi:10.1002/eji. 200737872

132. Okamoto Y, Tsutsumi H, Kumar NS, Ogra PL. Effect of breast feeding on the development of anti-idiotype antibody response to $\mathrm{F}$ glycoprotein of respiratory syncytial virus in infant mice after post-partum maternal immunization. J Immunol (1989) 142(7):2507-12.

133. Jarrett E, Hall E. Selective suppression of IgE antibody responsiveness by maternal influence. Nature (1979) 280(5718):145-7. doi:10.1038/280145a0

134. Ohsaki A, Venturelli N, Buccigrosso TM, Osganian SK, Lee J, Blumberg RS, et al. Maternal IgG immune complexes induce food allergen-specific tolerance in offspring. J Exp Med (2018) 215(1):91-113. doi:10.1084/jem.20171163

135. Okamoto Y, Freihorst J, Ogra PL. Maternal determinants of neonatal immune response to ovalbumin: effect of breast feeding on development 
of anti-ovalbumin antibody in the neonate. Int Arch Allergy Appl Immunol (1989) 89(1):83-9. doi:10.1159/000234928

136. Seeger M, Thierse HJ, Lange H, Shaw L, Hansen H, Lemke H. Antigenindependent suppression of the IgE immune response to bee venom phospholipase A2 by maternally derived monoclonal IgG antibodies. Eur J Immunol (1998) 28(7):2124-30. doi:10.1002/(SICI)1521-4141(199807)28: 07<2124::AID-IMMU2124>3.0.CO;2-A

137. Lange H, Kiesch B, Linden I, Otto M, Thierse HJ, Shaw L, et al. Reversal of the adult IgE high responder phenotype in mice by maternally transferred allergen-specific monoclonal IgG antibodies during a sensitive period in early ontogeny. Eur J Immunol (2002) 32(11):3133-41. doi:10.1002/15214141(200211)32:11<3133::AID-IMMU3133>3.0.CO;2-0

138. Perkin MR, Logan K, Tseng A, Raji B, Ayis S, Peacock J, et al. Randomized trial of introduction of allergenic foods in breast-fed infants. $N$ Engl J Med (2016) 374(18):1733-43. doi:10.1056/NEJMoa1514210

139. Stokholm J, Chawes BL, Vissing N, Bonnelykke K, Bisgaard H. Cat exposure in early life decreases asthma risk from the 17q21 high-risk variant. J Allergy Clin Immunol (2018) 141(5):1598-606. doi:10.1016/j.jaci.2017.07.044

140. Tanasa RI, Trad A, Lange H, Grotzinger J, Lemke H. Allergen IgE-isotypespecific suppression by maternally derived monoclonal anti-IgG-idiotype. Allergy (2010) 65(1):16-23. doi:10.1111/j.1398-9995.2009.02104.x

141. Cascalho M, Platt JL. Novel functions of B cells. Crit Rev Immunol (2007) 27(2):141-51. doi:10.1615/CritRevImmunol.v27.i2.20

142. Joao C. Immunoglobulin is a highly diverse self-molecule that improves cellular diversity and function during immune reconstitution. Med Hypotheses (2007) 68(1):158-61. doi:10.1016/j.mehy.2006.05.062

143. Marcos MA, De la Hera A, Pereira P, Marquez C, Toribio M, Coutinho A, et al. B cell participation in the recursive selection of T cell repertoires. Eur J Immunol (1988) 18(7):1015-20. doi:10.1002/eji.1830180707

144. Martinez C, Bernabe RR, de la Hera A, Pereira P, Cazenave PA, Coutinho A. Establishment of idiotypic helper T-cell repertoires early in life. Nature (1985) 317(6039):721-3. doi:10.1038/317721a0

145. Baumgarth N, Jager GC, Herman OC, Herzenberg LA. CD4+ T cells derived from B cell-deficient mice inhibit the establishment of peripheral B cell pools. Proc Natl Acad Sci U S A (2000) 97(9):4766-71. doi:10.1073/pnas.97.9.4766

146. Cohen IR. T-cell vaccination for autoimmune disease: a panorama. Vaccine (2001) 20(5-6):706-10. doi:10.1016/S0264-410X(01)00419-4

147. Volovitz I, Marmor Y, Mor F, Flugel A, Odoardi F, Eisenbach L, et al. T cell vaccination induces the elimination of EAE effector T cells: analysis using GFP-transduced, encephalitogenic T cells. J Autoimmun (2010) 35(2):13544. doi:10.1016/j.jaut.2010.05.003

148. Herkel J, Brunner S, Meyer zum Buschenfelde KH, Lohse AW. Humoral mechanisms in $\mathrm{T}$ cell vaccination: induction and functional characterization of anti-lymphocytic autoantibodies. J Autoimmun (1997) 10(2):137-46. doi:10.1006/jaut.1997.0125

149. Karpus WJ, Swanborg RH. Protection against experimental autoimmune encephalomyelitis requires both CD4+ $\mathrm{T}$ suppressor cells and myelin basic protein-primed B cells. J Neuroimmunol (1991) 33(2):173-7. doi:10.1016/0165-5728(91)90061-B

150. Huang $\mathrm{X}, \mathrm{Wu} \mathrm{H}, \mathrm{Lu} \mathrm{Q}$. The mechanisms and applications of $\mathrm{T}$ cell vaccination for autoimmune diseases: a comprehensive review. Clin Rev Allergy Immunol (2014) 47(2):219-33. doi:10.1007/s12016-014-8439-6
151. Dhaeze T, Stinissen P, Liston A, Hellings N. Humoral autoimmunity: a failure of regulatory T cells? Autoimmun Rev (2015) 14(8):735-41. doi:10.1016/j. autrev.2015.04.006

152. Linterman MA, Pierson W, Lee SK, Kallies A, Kawamoto S, Rayner TF, et al. Foxp3+ follicular regulatory T cells control the germinal center response. Nat Med (2011) 17(8):975-82. doi:10.1038/nm.2425

153. Chung Y, Tanaka S, Chu F, Nurieva RI, Martinez GJ, Rawal S, et al. Follicular regulatory T cells expressing Foxp3 and Bcl-6 suppress germinal center reactions. Nat Med (2011) 17(8):983-8. doi:10.1038/nm.2426

154. Wollenberg I, Agua-Doce A, Hernandez A, Almeida C, Oliveira VG, Faro J, et al. Regulation of the germinal center reaction by Foxp3+ follicular regulatory T cells. J Immunol (2011) 187(9):4553-60. doi:10.4049/ jimmunol.1101328

155. Blier PR, Bothwell AL. The immune response to the hapten NP in C57BL/6 mice: insights into the structure of the B-cell repertoire. Immunol Rev (1988) 105:27-43. doi:10.1111/j.1600-065X.1988.tb00764.x

156. McHeyzer-Williams MG, McLean MJ, Lalor PA, Nossal GJ. Antigen-driven B cell differentiation in vivo. J Exp Med (1993) 178(1):295-307. doi:10.1084/ jem.178.1.295

157. Brezinschek HP, Foster SJ, Dorner T, Brezinschek RI, Lipsky PE. Pairing of variable heavy and variable kappa chains in individual naive and memory B cells. J Immunol (1998) 160(10):4762-7.

158. Rosner K, Winter DB, Tarone RE, Skovgaard GL, Bohr VA, Gearhart PJ. Third complementarity-determining region of mutated $\mathrm{VH}$ immunoglobulin genes contains shorter $\mathrm{V}, \mathrm{D}, \mathrm{J}, \mathrm{P}$, and $\mathrm{N}$ components than non-mutated genes. Immunology (2001) 103(2):179-87. doi:10.1046/j.1365-2567.2001.01220.x

159. Jacob J, Przylepa J, Miller C, Kelsoe G. In situ studies of the primary immune response to (4-hydroxy-3-nitrophenyl)acetyl. III. The kinetics of V region mutation and selection in germinal center B cells. J Exp Med (1993) 178(4):1293-307. doi:10.1084/jem.178.4.1293

160. Heiser RA, Snyder CM, St Clair J, Wysocki LJ. Aborted germinal center reactions and $\mathrm{B}$ cell memory by follicular $\mathrm{T}$ cells specific for a B cell receptor V region peptide. J Immunol (2011) 187(1):212-21. doi:10.4049/jimmunol. 1002328

161. Hu D, Ikizawa K, Lu L, Sanchirico ME, Shinohara ML, Cantor H. Analysis of regulatory CD8 T cells in Qa-1-deficient mice. Nat Immunol (2004) 5(5):516-23. doi:10.1038/ni1063

162. Polonelli L, Beninati C, Teti G, Felici F, Ciociola T, Giovati L, et al. Yeast killer toxin-like candidacidal Ab6 antibodies elicited through the manipulation of the idiotypic cascade. PLoS One (2014) 9(8):e105727. doi:10.1371/journal. pone. 0105727

Conflict of Interest Statement: The author declares that he has neither commercial nor any financial relationships that could be construed as a potential conflict of interest.

Copyright (c) 2018 Lemke. This is an open-access article distributed under the terms of the Creative Commons Attribution License (CC BY). The use, distribution or reproduction in other forums is permitted, provided the original author(s) and the copyright owner are credited and that the original publication in this journal is cited, in accordance with accepted academic practice. No use, distribution or reproduction is permitted which does not comply with these terms. 